\title{
The impact of the weather conditions on the cooling performance of the heat pump driven by an internal natural gas combustion engine
}

\author{
Martina Janovcová ${ }^{1, a}$, Jozef Jandačka ${ }^{1}$ and Milan Malcho ${ }^{1}$ \\ ${ }^{1}$ University of Žilina, Faculty of Mechanical Engineering, Department of Power Engineering, Univerzitná 1, \\ 01026 Žilina. Slovakia
}

\begin{abstract}
Market with sources of heat and cold offers unlimited choice of different power these devices, design technology, efficiency and price categories. New progressive technologies are constantly discovering, about which is still little information, which include heat pumps powered by a combustion engine running on natural gas. A few pieces of these installations are in Slovakia, but no studies about their work and effectiveness under real conditions. This article deals with experimental measurements of gas heat pump efficiency in cooling mode. Since the gas heat pump works only in system air - water, air is the primary low energy source, it is necessary to monitor the impact of the climate conditions for the gas heat pump performance.
\end{abstract}

\section{Introduction}

Gas heat pump (GHP) is an innovative technology for the production of heat or cold. The great advantage of gas heat pump is the possibility of obtaining heat from the engine cooling and exhaust system as in Figure 1. Outdoor air is the primary energy source of obtaining heat. To drive the compressor uses a gas engine running on natural gas respectively LPG. Gas heat pump is characterized by low operating costs thanks to its robust construction and technology maintenance is minimal. [1]

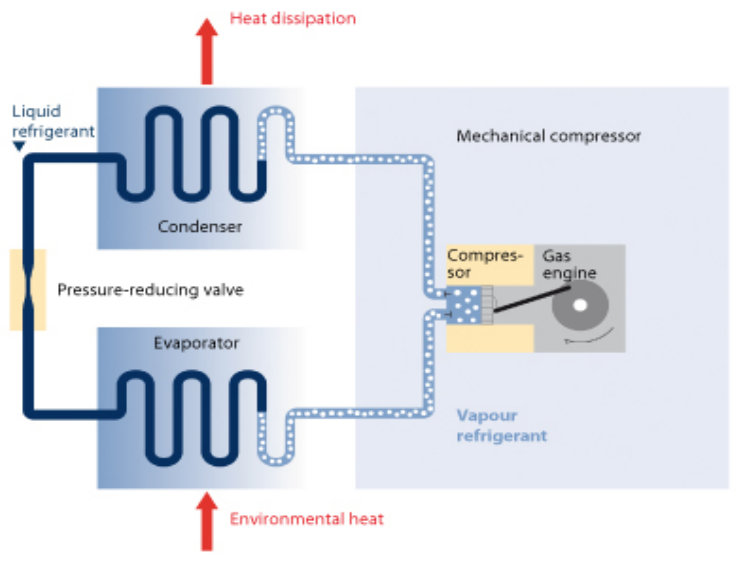

Figure 1. Gas heat pump.

The cooling circuit of the heat pump uses R410A refrigerant (CFC-free refrigerant with zero ozone decay coefficient). GHP can be used not only in systems with direct expansion refrigerant (air conditioning systems), but also in systems such as heat transfer medium water use, thus the opportunity to re-use existing distribution pipelines in renovated buildings. [2]

\section{Energy efficiency ratio (EER) and Primary energy ratio (PER)}

Evaluation of the efficiency of the GHP is similar to that of heating and is defined on the basis of two factors EER and PER. Energy efficiency ratio (EER) is the ratio of the produced cooling capacity and electricity or gas supplied to the device. [3]

$$
E E R=\frac{\text { cooling _ power }}{\text { energy_consumed }} .
$$

Primary energy rate (PER) compares the efficiency of energy systems with different types of fuel and energy produced. PER is generally the ratio of all the available energy in the system to produce a useful energy. The system, which has a lower value of PER using less primary energy per unit of useful energy, and thus the system is more energy efficient. [4] [5]

$$
P E R=\frac{G_{H P}+\frac{E_{e l H P}}{\eta_{e l}}}{Q_{H P}},
$$

a martina.janovcova@fstroj.uniza.sk 
where: $G_{M F}$ is the energy of gas supplied to the heat pump (kWh), pump (kWh),

$E_{\text {ellar }}$ is the electricity supplied to the heat $(35 \%)$ pump (kWh).

$\eta_{e l}$ is the efficiency of electricity production

PER coefficient implies also power consumption of the drive system circulators. [6] This electrical energy is also related to the efficiency of electricity production. Based on the value of PER can be compared also energy systems with different input power. [7]

\section{Specification of gas heat pump}

To experimentally measurement the operating parameters of the gas heat pump air / water was chosen gas heat pump Toyota AISIN 10HP model AXYGP 280 E1. Its parameters are shown in Table 1.

Table 1. Technical specification of gas heat pump.

\begin{tabular}{|c|c|c|c|c|}
\hline \multicolumn{4}{|c|}{ Toyota AISIN 10HP } & \multirow{2}{*}{$\begin{array}{l}\text { Model } \\
\text { AXYG } \\
\text { P 280 } \\
\text { E1 } \\
28\end{array}$} \\
\hline \multirow{3}{*}{$\begin{array}{l}\text { Rated } \\
\text { output }\end{array}$} & \multicolumn{2}{|c|}{ Rated cooling capacity } & $\mathrm{kW}$ & \\
\hline & \multicolumn{2}{|c|}{ Rated heating capacity } & $\mathrm{kW}$ & 31.5 \\
\hline & \multicolumn{2}{|c|}{$\begin{array}{l}\text { Maximum heating } \\
\text { capacity }\end{array}$} & $\mathrm{kW}$ & 33.5 \\
\hline \multirow{3}{*}{$\begin{array}{l}\text { Electrical } \\
\text { features }\end{array}$} & \multicolumn{2}{|c|}{ Power supply } & $\mathrm{V}$ & 230 \\
\hline & \multirow{2}{*}{$\begin{array}{l}\text { Power } \\
\text { consump } \\
\text { tion }\end{array}$} & Cooling & $\mathrm{kW}$ & 0.44 \\
\hline & & Heating & $\mathrm{kW}$ & 0.258 \\
\hline \multirow{2}{*}{$\begin{array}{l}\text { Consump } \\
\text { tion }\end{array}$} & \multirow{2}{*}{$\begin{array}{l}\text { Gas } \\
\text { consump } \\
\text { tion } \\
\end{array}$} & Cooling & $\mathrm{kW}$ & 19.2 \\
\hline & & Heating & $\mathrm{kW}$ & 20.3 \\
\hline \multirow[t]{3}{*}{ Engine } & \multicolumn{2}{|c|}{ Rated output } & $\mathrm{kW}$ & 6.2 \\
\hline & \multirow[t]{2}{*}{$\begin{array}{l}\text { Revolution } \\
\text { range }\end{array}$} & Cooling & $\mathrm{rpm}$ & $\begin{array}{l}800- \\
1550\end{array}$ \\
\hline & & Heating & $\mathrm{rpm}$ & $\begin{array}{l}800- \\
2700\end{array}$ \\
\hline \multirow{3}{*}{$\begin{array}{l}\text { Compres } \\
\text { sor }\end{array}$} & \multicolumn{3}{|l|}{ Type } & Scroll \\
\hline & \multirow[t]{2}{*}{$\begin{array}{l}\text { Revolution } \\
\text { range }\end{array}$} & Cooling & $\mathrm{rpm}$ & $\begin{array}{l}1640- \\
3178 \\
\end{array}$ \\
\hline & & Heating & $\mathrm{rpm}$ & $\begin{array}{l}1640- \\
5535\end{array}$ \\
\hline \multirow{3}{*}{$\begin{array}{l}\text { External } \\
\text { dimensio } \\
\mathrm{n}\end{array}$} & \multicolumn{2}{|l|}{ Heigh } & $\mathrm{mm}$ & 2077 \\
\hline & \multicolumn{2}{|l|}{ Width } & $\mathrm{mm}$ & 1400 \\
\hline & \multirow{2}{*}{\multicolumn{2}{|c|}{ Depth }} & $\mathrm{mm}$ & 880 \\
\hline Weight & & & $\mathrm{kg}$ & 570 \\
\hline
\end{tabular}

\subsection{Advantages of gas heat pump}

- Modern and energy-efficient system (multiple heat sources - ambient air, cooling circuit of the engine, exhaust system).

- Exceptional thermal performance.
- Does not require any special maintenance.

- A significant reduction in emissions of greenhouse gases (ecological system).

- Heating a room without interruption to defrost.

- Installation is not necessary boiler room, or earthworks.

- Low operating costs (saving money). [8]

All season-saving with gas heat pump amount to $30 \%$ to $50 \%$ compared to electric heat pumps and other sources of heat. Gas heat pump burns natural gas or liquefied petroleum gas ( $\mathrm{CNG}$ or $\mathrm{LPG}$ ) to drive the compressor. Price ratio for producing $1 \mathrm{~kW}$ between gas and electricity in the long term maintained at a ratio of 1: 4 in favor of gas.

\subsection{Operating parameters of the gas heat pump given by producer}

In Table 2 lists the operating parameters such as capacity, consumption and energy efficiency ratio of the gas heat pump at various degrees of power load and different outdoor temperature given by producer. [9]

Table 2. Operating parameters of GHP.

\begin{tabular}{|c|c|c|c|c|}
\hline \multicolumn{5}{|c|}{ COOLING MODE } \\
\hline \multirow{3}{*}{$\begin{array}{l}\text { Load } \\
\text { factor }\end{array}$} & \multirow{3}{*}{$\begin{array}{c}\text { Outdoor } \\
\text { Temperature } \\
\text { DB }\end{array}$} & \multicolumn{3}{|c|}{$\begin{array}{c}\text { Indoor unit intake air } \\
\text { temperature WB }\end{array}$} \\
\hline & & \multicolumn{3}{|c|}{19.00} \\
\hline & & Capacity & $\begin{array}{c}\text { Consump } \\
\text { tion }\end{array}$ & EER \\
\hline \multirow{4}{*}{$\stackrel{\circ}{8}$} & 25.00 & 31.10 & 16.20 & 1.92 \\
\hline & 30.00 & 29.60 & 17.70 & 1.67 \\
\hline & 35.00 & 28.00 & 19.20 & 1.46 \\
\hline & 40.00 & 26.30 & 21.00 & 1.25 \\
\hline \multirow{4}{*}{ ஓें } & 25.00 & 28.00 & 13.50 & 2.07 \\
\hline & 30.00 & 26.60 & 14.70 & 1.81 \\
\hline & 35.00 & 25.20 & 16.10 & 1.57 \\
\hline & 40.00 & 23.70 & 17.50 & 1.35 \\
\hline \multirow{4}{*}{$\grave{\infty}_{0}^{\circ}$} & 25.00 & 24.90 & 11.30 & 2.20 \\
\hline & 30.00 & 23.60 & 12.30 & 1.92 \\
\hline & 35.00 & 22.40 & 13.60 & 1.66 \\
\hline & 40.00 & 21.10 & 14.70 & 1.44 \\
\hline \multirow{4}{*}{ @े } & 25.00 & 21.70 & 9.40 & 2.31 \\
\hline & 30.00 & 20.70 & 10.30 & 2.01 \\
\hline & 35.00 & 19.60 & 11.30 & 1.73 \\
\hline & 40.00 & 18.40 & 12.40 & 1.48 \\
\hline \multirow{4}{*}{ 8ें } & 25.00 & 18.60 & 7.80 & 2.38 \\
\hline & 30.00 & 17.70 & 8.50 & 2.08 \\
\hline & 35.00 & 16.80 & 9.40 & 1.79 \\
\hline & 40.00 & 15.80 & 10.30 & 1.53 \\
\hline \multirow{4}{*}{ தें } & 25.00 & 15.50 & 6.70 & 2.31 \\
\hline & 30.00 & 14.80 & 7.30 & 2.03 \\
\hline & 35.00 & 14.00 & 8.00 & 1.75 \\
\hline & 40.00 & 13.20 & 8.70 & 1.52 \\
\hline
\end{tabular}




\subsection{Weather station}

Because of GHP is working on the principle of air water, it is taking heat from low potential primary source from the outside environment. The weather station eas installed from producer AHLBORN on the roof of the building. [8]

The weather station consists of measuring devices that measure the following parameters:

- rainfall [mm],

- outside air temperature $\left[{ }^{\circ} \mathrm{C}\right]$,

- wind direction $\left[{ }^{\circ}\right]$,

- wind speed $\left[\mathrm{m} . \mathrm{s}^{-1}\right]$,

- relative humidity [\%],

- global radiation $\left[\mathrm{W} \cdot \mathrm{m}^{-2}\right]$.

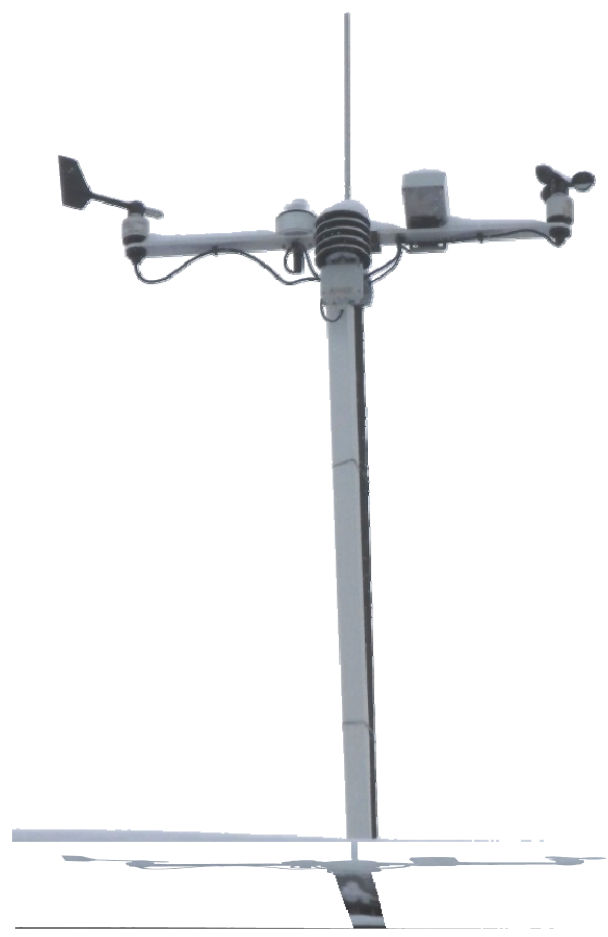

Figure 2. Weather station.

\section{Experimental measurement of gas heat pump air / water}

Experimental measurement of the gas heat pump Toyota AISIN 10HP model AXYGP 280 E1 was implemented in the University of Žilina in Žilina, Faculty of Mechanical Engineering in the period from 07/18/2013 to $07 / 25 / 2013$, as in Figure 3. GHP worked all the time in cooling mode and air-conditioning served laboratories on the University of Žilina. Total nominal cooling capacity of GHP is $28 \mathrm{~kW}$. The required temperature gradient on the secondary side was $6{ }^{\circ} \mathrm{C}$. The measured parameters were recorded at minute intervals and evaluated according to expression (1) and (2). Subsequently evaluated hourly average parameters characterizing the operation of the gas heat pump and finally establish an average daily values and was prepared by the relevant graphs.

GHP is composed of external and internal units interconnected refrigerant circuit. The outdoor unit contains the heat exchanger air / coolant, a compressor, a combustion engine and a heat exchanger for preheating the refrigerant. The inner side is the so-called technological unit AWS (Air - Water System), which is used to transfer heat respectively cold from the refrigerant circuit to the water. HOTKIT is part of the experimental device and is composed of heat exchanger water - water that is used to cool the engine. The water of the AWS and the HOTKIT is distributed in the distributor and is used for heating or cooling corridors and laboratories of the University of Žilina. The sensors of temperature, pressure and flow are installed as shown in Figure 3. Measured parameters are recorded and saved in the PC.

Individual measured parameters were recorded at minute intervals and then were calculated the hourly averages. For each day were measured, among other parameters necessary to determine the energy efficiency of the heat pump:

- Consumption of natural gas $\left[\mathrm{m}^{3}\right]$,

- Electricity consumption [kWh],

- HOTKIT outlet temperature $\left[{ }^{\circ} \mathrm{C}\right]$,

- HOTKIT inlet temperature $\left[{ }^{\circ} \mathrm{C}\right]$,

- HOTKIT flow $\left[\mathrm{m}^{3} / \mathrm{h}\right]$,

- AWS outlet temperature $\left[{ }^{\circ} \mathrm{C}\right]$,

- AWS inlet temperature $\left[{ }^{\circ} \mathrm{C}\right]$,

- AWS flow $\left[\mathrm{m}^{3} / \mathrm{h}\right]$.

Simultaneously were recorded outdoor climate conditions. The graphs were drawn from the measured data, up for each day of measurement and finally to evaluate the entire measurement time.

The efficiency of the heat pump is affected more factors. Crucial factor is the quality of components, structural layout and dimensions are sufficient to guarantee the equipment manufacturer. Important is also control regulatory system of heat pump to ensure optimum use of technology and thus its maximum efficiency of operation. Operating parameters such as flow temperature, pressure and flow media also have an impact on the overall performance of the heat pump. As mentioned above, gas heat pumps exist in the system air / water. As the air reaches during large temperature fluctuations have a significant impact on the efficiency of the heat pump. In winter, when the demand for heat reaches the largest low temperatures the other hand in the summer when the need for cooling the temperature is high. [10] 


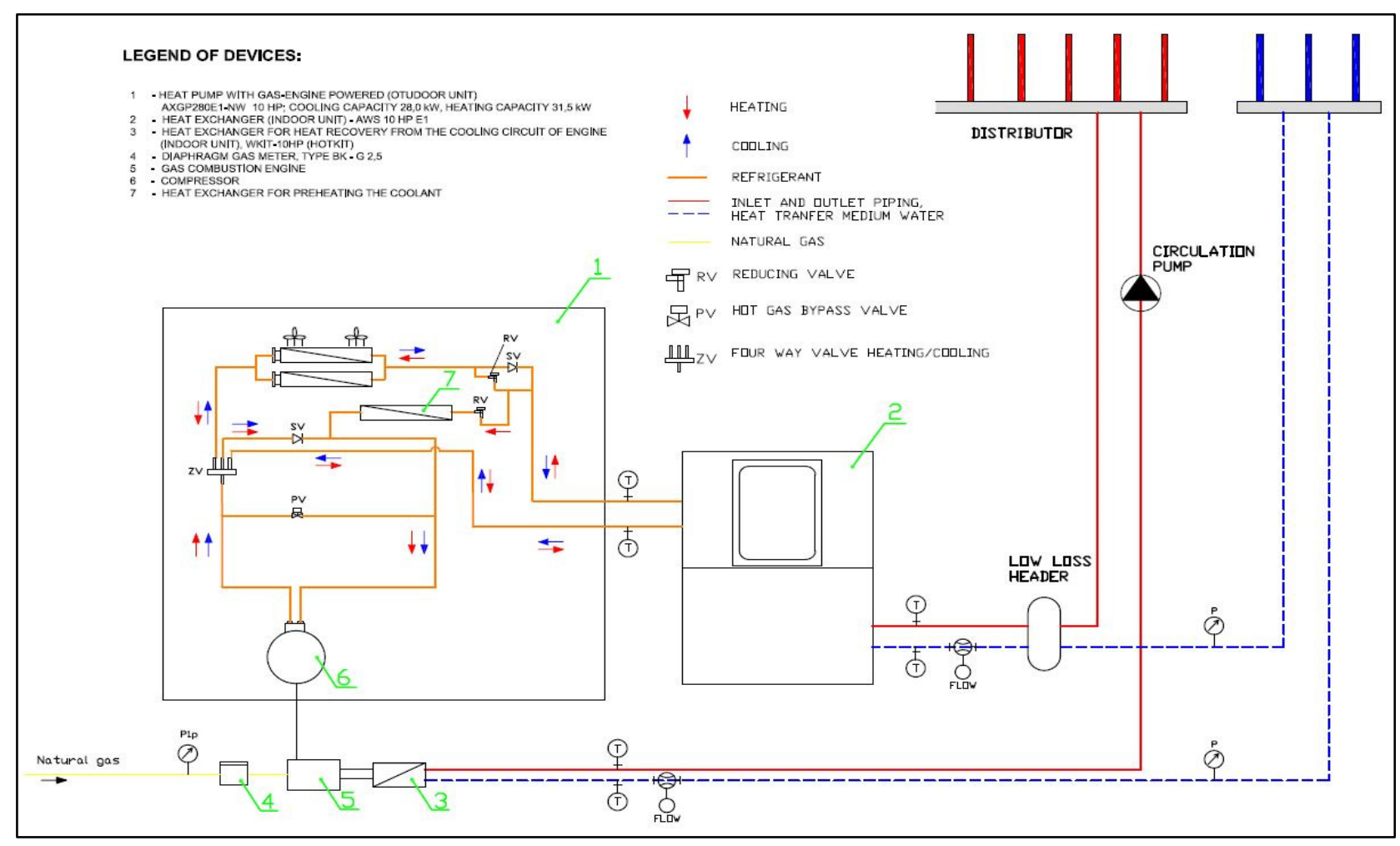

Figure 3. Technological diagram of gas heat pump air / water.

\section{Result of measurement}

The measurement was realized for a period from $07 / 18 / 2013$ to $07 / 25 / 2013$. GHP worked at all times in the cooling mode. The biggest impact on performance of GHP had the temperature of low-potential heat source. During the measurement was achieved maximum outdoor air temperature $28{ }^{\circ} \mathrm{C}$ on $07 / 19 / 2013$ between $16: 00$ and 16:59. Mainly for this reason, this day has chosen to represent the individual working parameters shown in the following Figures.

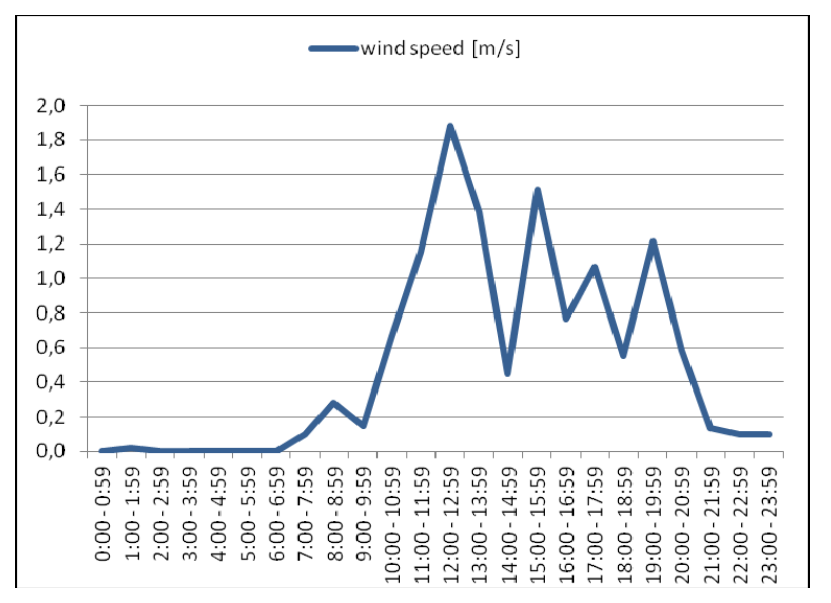

Figure 4. Wind speed (07/19/2013).

The following illustrations show the average hourly values from the weather station on 19/07/2013.

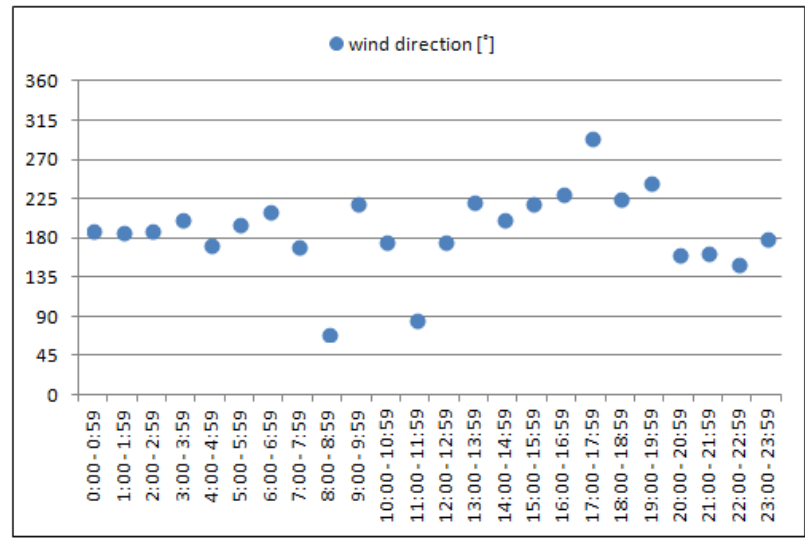

Figure 5. Wind direction (07/19/2013).

Figure 4 and 5 shows the speed and direction of wind in the day of measurement. During the measurement of wind speed did not reach high values.

Wind direction is defined in degrees from north, Table 3 shows the relationship between degrees and cardinal. [11]

Table 3. Wind direction.

\begin{tabular}{|l|l|}
\hline SV & $45^{\circ}$ \\
\hline $\mathrm{V}$ & $90^{\circ}$ \\
\hline $\mathrm{JV}$ & $135^{\circ}$ \\
\hline $\mathrm{JV}$ & $180^{\circ}$ \\
\hline $\mathrm{JZ}$ & $225^{\circ}$ \\
\hline $\mathrm{Z}$ & $270^{\circ}$ \\
\hline $\mathrm{SZ}$ & $315^{\circ}$ \\
\hline $\mathrm{S}$ & $360^{\circ}$ \\
\hline
\end{tabular}


Other parameters are measured rainfall, relative humidity and global solar radiation shown in Figure 6 and 7. Throughout the measurements rainfall was zero. The average daily relative humidity was $62 \%$.

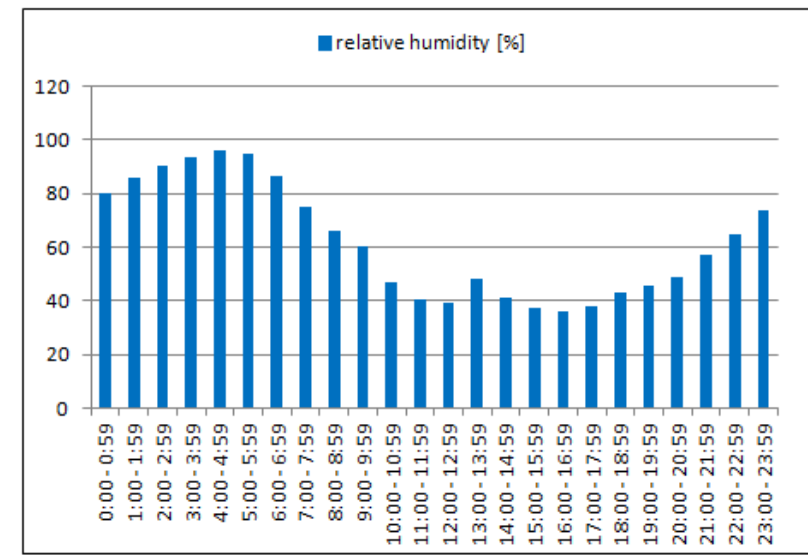

Figure 6. Relative humidity (07/19/2013).

The values of global solar radiation were measured in the range from 0 to $1200 \mathrm{~W} / \mathrm{m}^{2}$.

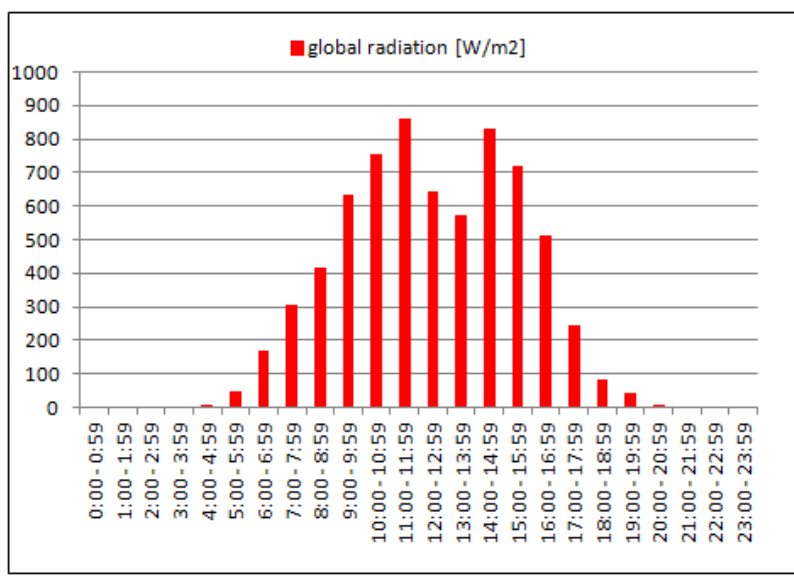

Figure 7. Global radiation (07/19/2013).

Greatest impact on the performance of the gas heat pump air-water system has the ambient temperature. On that day was to reach maximum temperature of $28{ }^{\circ} \mathrm{C}$ between 16:00 and 16:59 and minimum $13.5{ }^{\circ} \mathrm{C}$ from $4: 00$ and $4: 59$.

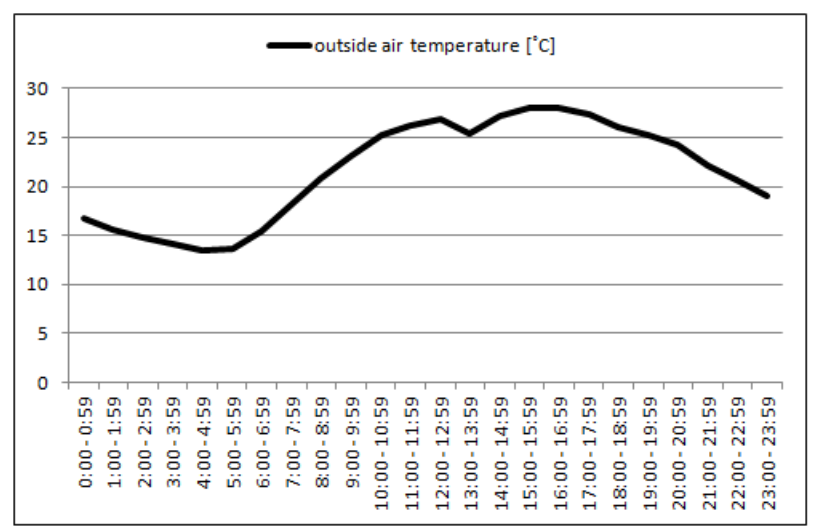

Figure 8. Outside air temperature (07/19/2013).
By measuring was determined energy efficiency of this modern heat and cold source in the cooling mode. GHP manufacturer indicates EER values listed in Table 2. In Table 2 are the values of GHP rated output, outside air temperature and cooling factor values. Total nominal cooling capacity of GHP is $28 \mathrm{~kW}$. The required temperature gradient on the secondary side was $6{ }^{\circ} \mathrm{C}$. The measured parameters were recorded at minute intervals and evaluated according to expression (1) and (2). Subsequently evaluated hourly average parameters characterizing the operation of the gas heat pump and finally establish an average daily values and was prepared by the relevant graphs.

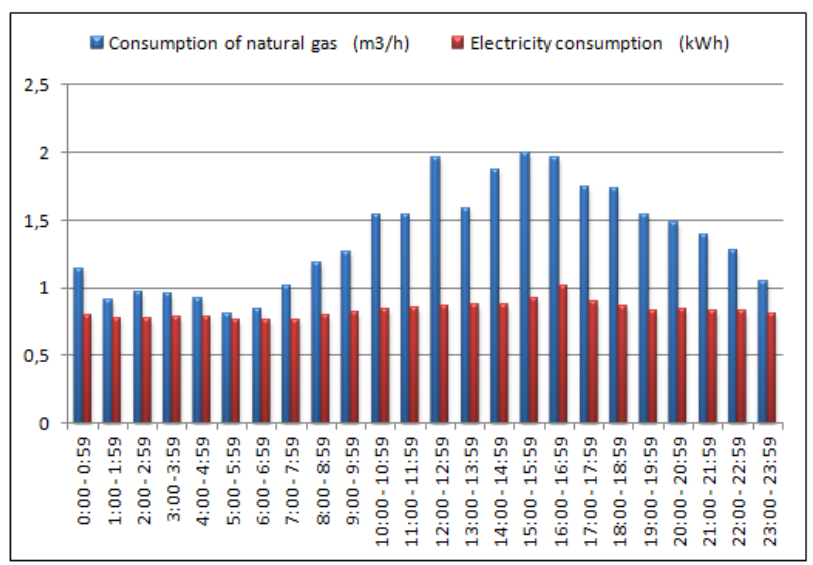

Figure 9. Energy consumption (07/19/2013).

Figure 9 shows the power consumption for the circulation pump and natural gas consumption. Electricity consumption was constant and reached an hourly average $0.83 \mathrm{kWh}$. Hourly consumption of natural gas was in the range from $0.8 \mathrm{~m}^{3} / \mathrm{h}$ to $2 \mathrm{~m}^{3} / \mathrm{h}$, depending on the need for cooling and outdoor air temperature.

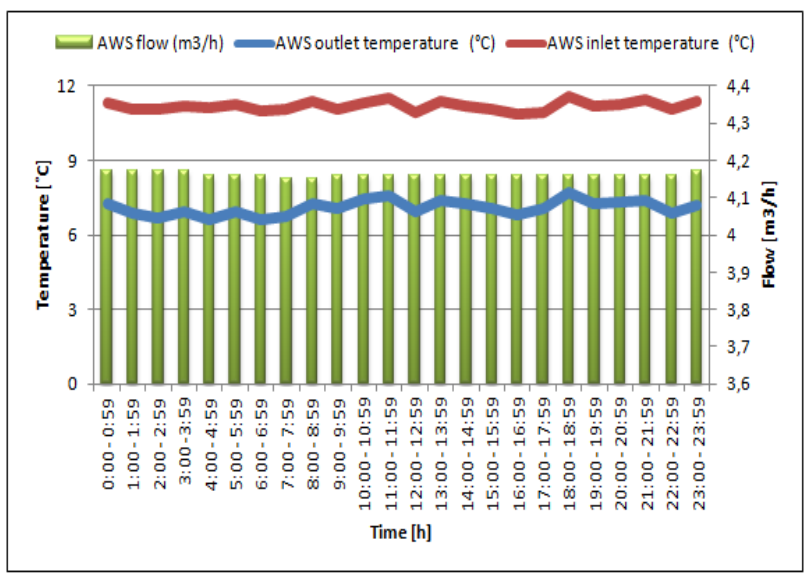

Figure 10. Temperature and water flow on the secondary side of GHP (07/19/2013).

Gradient of water temperature on the secondary side was $4,1^{\circ} \mathrm{C}$. The water flow was also constant at $4.2 \mathrm{~m}^{3} / \mathrm{h}$ as shown figure 10 . 
Figure 11 shows the EER and PER of experimental equipment, depending on the average hourly outside air temperature. The average daily outside temperature was the ranged from 13.5 to $28{ }^{\circ} \mathrm{C}$. Coefficient EER reached a value from 0.93 to 2.48 and primary energy rate $\mathrm{PER}=$ $0.51-1.21$.

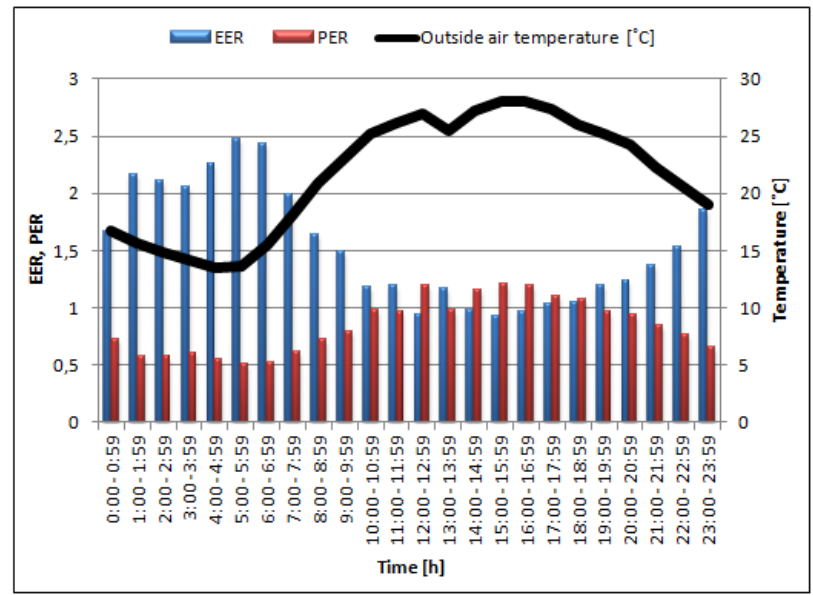

Figure 11. Average hourly values of PER and EER of gas heat pump depending on the outside air temperature. (07/19/2013).

The Figure 11 is a chart to demonstrate the dependence of EER to outside temperature. When the outside air temperature reached the highest value $\left(28^{\circ} \mathrm{C}\right)$, it also responds to the lowest achievable EER (0.93) in a given hour.

As indicated above, the gas heat pump has a total power of $28 \mathrm{~kW}$ of cooling. Rated power of the experimental device for measuring time averaged $20 \mathrm{~kW}$, ie gas heat pump operates at $70 \%$. [12]

\section{Conclusion}

The measurement of GHP in cooling mode achieved during the whole measurement period (07/18/2013 $07 / 25 / 2013$ ) the average value of the cooling factor EER $=1.7$ and PER $=0.77$. Average outside temperature throughout the measurement period reached $20.8{ }^{\circ} \mathrm{C}$. Gas heat pump working all the time in the cooling mode and the load was $70 \%$. Measured values of cooling factor are slightly different from the tabulated values, which are given by the producer of GHP. In spite of this fact can be confirmed that the heat pump to work efficiently also when the outside air temperature reached $28{ }^{\circ} \mathrm{C}$. When changes in work load and experimental facilities, this new and modern heat and cold source has a great potential to compete in today's market as a source of heat and cold.

\section{Acknowledgement}

This article was created within the frame of project KEGA 070ZU-4/2013 "Modern sources for heating".

This paper is supported by the following project: University Science Park of the University of Zilina (ITMS: 26220220184) supported by the
Research\&Development Operational Program funded by the European Regional Development Fund.

\section{References}

1. http://www.yzamer.sk/produkty/tepelnecerpadla/plynove-tepelne-cerpadla, Gas heat pumps

2. E. Bakker at al. Gas heat pumps. Efficient heating and cooling with natural gas. (GasTerra/Castel international Publishers, Netherlands, 2010)

3. B. Langeley. Heat pump technology. (Prentice Hall. 2001)

4. M. Malcho, A. Kapjor, J. Hužvár. Measurement of heat pumps air - water (2011)

5. A. Hepbasli at al. A review of gas engine driven heat pumps (GEHPS) for residential and industrial applications. (Elsevier, 2009)

6. norma STN EN 15316 - 4 - 2: Heating systems in buildings - Method for calculation of system energy requirements and system efficiencies - Part 4 - 2: Space heating generation systems, heat pump systems.

7. O. Ozgener and A. Hepbasli, A review on the energy and exergy analysis of solar assisted heat pump systems, (Renewable Sustainable Energy Rev, 2007)

8. M. E. Jonsson and E. Granryd, Multipurpose heat pump for domestic applications, (E2 \& B2- Linz, Austria, 1997)

9. Janovcová, M., Kiš, R., Jandačka, J, Malcho, M., Kapjor, A.: Conversion efficiency of natural gas to heat into the gas engine-driven heat pump (2013)

10. http://www.tecnocasa.com/EN/Default.aspx?level0=home, Gas heat pump.

11. http://www.ahlborn.com/, Measuring instruments and sensors. (Product catalog, 2009)

12. A.Čaja, Z. Kolková : Vplyv konštrukcie chladiča na schopnost' odvádzania tepla z kondenzačnej časti tepelnej trubice. (Žilina, 2013) 